\title{
SAME SEX UNIONS OF LIFE IN THE PRACTICE OF THE EUROPEAN COURT OF JUSTICE
}

\section{Boris Krešić ${ }^{1}$}

Faculty of Law Tuzla, University of Tuzla

\author{
Scientific review
}

UDC: $347.62-055.3$

Received: 14.11.2013.

Accepted: 13.11.2013.

\begin{abstract}
In several cases the the European Court of Justice (ECJ) interpreted the provisions of the Agreement on the European Community in terms of homosexual rights. The practice of the ECJ in the last five years (2008-2013) shows the tendency to expand the rights of homosexual persons. The paper brings the analysis of four decision of the ECJ in the cases where it decided on the issue of discrimination on grounds of sexual orientation. In the first two verdicts, the Court refused to compare marriage and common-law marriage to the same-sex union of life, thus limiting same-sex partners to achieve certain rights. In other two cases the Court made step forward and compared marriage and same-sex union of life but only if both, marriage and same-sex union of life are regulated by national law.
\end{abstract}

Key words: European Court of Justice (ECJ), same-sex union of life, discrimination, registered partnership

\section{INTRODUCTION}

The European Court of Justice (hereinafter ECJ) is the highest legal instance of the European Union. It was established in 1952 by the Treaty of Paris as part of the European Coal and Steel Community. It became an institution of two additional Communities in 1957 when the European Economic Community (EEC), and the European Atomic Energy Community (Euratom) were created, sharing the same courts with the European Coal and Steel Community. The seat of the Court is in Luxembourg ${ }^{2}$.

\section{${ }^{1}$ Correspodence to:}

Boris Krešić, Faculty of Law Tuzla, University of Tuzla Sjever d4, Živinice, B\&H

Phone: +38761639233

E-mail: b_kresic@yahoo.com

\footnotetext{
${ }^{2}$ Following the Treaty of Lisbon the Court of Justice is composed of 27 Judges and nine Advocates General. The Judges and Advocates General are appointed by common accord of the governments of the Member States They are appointed for a term of office of six years, which is renewable. The Judges of the Court of Justice elect from amongst themselves a President and a Vice-President for a renewable term of three years. http://curia. europa.eu/jcms/jcms/Jo2_7024/ accessed April 2011.
} 
In order to facilitate the work of this Court, in 1988 the Court of First Instance was established. Thus, the ECJ is comprised of two courts, the Court of the European Community and the Court of First Instance ${ }^{3}$. Pursuant to Article 234 of the Agreement on the European Community (hereinafter the AEC), ECJ has jurisdiction to bring the preliminary rulings on the interpretation of the AEC and acts of the institutions of the European Community (EC) as well as on the validity of the acts ${ }^{4}$. Article 234 of the AEC specifies two types of authority, meaning the obligations of the national courts. The courts against whose rulings the legal remedy can be filed have the authority but not the obligation to seek for the interpretation of European law from the ECJ.

Courts of last instance, on the other hand, are obliged to initiate proceedings when a disputable issue appears before them that is related to the interpretation of the European norm applicable in a case. Preliminary proceedings that can or sometimes need to be initiated by national courts before the ECJ is the most

\footnotetext{
${ }^{3}$ The European Parliament and the Council, acting in accordance with the ordinary legislative procedure, may establish specialised courts attached to the General Court to hear and determine at first instance certain classes of action or proceeding brought in specific areas. The European Parliament and the Council shall act by means of regulations either on a proposal from the Commission after consultation of the Court of Justice or at the request of the Court of Justice after consultation of the Commission. The regulation establishing a specialised court shall lay down the rules on the organisation of the court and the extent of the jurisdiction conferred upon it. Article 257 The Treaty of Lisbon. http://www.lisbon-treaty.org/wcm/the-lisbon-treaty/treaty-on-the-functioning-of-the-european-union-and-comments/ part-6-institutional-and-financial-provisions/title-1-institutional-provisions/chapter-1-the-institutions/section-5-the-court-ofjustice-of-the-european-union/552-article-257.html accessed April 2011

${ }^{4}$ Article 234 The Treaty of Lisbon:
}

The Court of Justice shall have jurisdiction to give preliminary rulings concerning:

(a) the interpretation of this Treaty;

(b) the validity and interpretation of acts of the institutions of the Community and of the ECB;

(c) the interpretation of the statutes of bodies established by an act of the Council, where those statutes so provide.

Where such a question is raised before any court or tribunal of a Member State, that court or tribunal may, if it considers that a decision on the question is necessary to enable it to give judgment, request the Court of Justice to give a ruling thereon.

Where any such question is raised in a case pending before a court or tribunal of a Member State against whose decisions there is no judicial remedy under national law, that court or tribunal shall bring the matter before the Court of Justice.http://eur-lex.europa.eu/LexUriServ/LexUriServ. do?uri=CELEX:12002E234:EN:NOT accessed April 2011. significant procedure for the development of European law. Its basic purpose is to ensure a uniform implementation of the Community's law. To wit, owing to the direct effect of the ECJ rulings, European law is implemented daily by numerous courts of the member states that belong to different legal cultures. Therefore, it is easily possible that the same norm before different courts be understood differently. In order to avoid this, the Agreement specifies the preliminary proceeding that enables the final interpretation of European law, binding to all national courts, to be given by one institution - the ECJ.

What is important in this procedure is certainly not the fact that the ECJ is authorized to interpret European law. The ECJ certainly does it in all other procedures as well, since the interpretation of law is a necessary step when bringing any court rulings and the ECJ authorization would by per se unnecessary. Article 234 of AEC is not important because it gives the ECJ the authorization to interpret European law but because the ECJ interpretation is binding to all national courts ${ }^{5}$.

\section{Lisa Jacqueline Grant v. South-West Trains Ltd}

The ECJ first discussed the rights of homosexual persons in the case Lisa Jacqueline Grant v. South-West Trains Ltd $^{6}$. The applicant Lisa Grant worked for an air-line company and travelled for free for many years. At the time she had already been living in a union of life with her partner for two years and she wanted to ensure for her the same benefits as those given to other employees of the air-line company and their unmarried partners. Her superior informed her that she cannot be granted the same benefits like other employees due to the fact that she is in a same-sex union of life. Lisa Grant sued South-West Trains Ltd (hereinafter SWTL) to the Industrial Court in Southampton on charges of discrimination on grounds of sexual orientation.

${ }^{5}$ The interpretation of European law, whether given in the preliminary proceedings or in other proceedings by the ECJ, is obligatory for all national courts in all current and future proceedings. In that way, the ECJ interpretations have erga omnes effects. See Flaminio verdict: Case 6/64 Costa v. E.N.E.L. http://eur-lex.europa.eu/LexUriServ/LexUri Servb. do?uri=CELEX:61964J0006:en:HTML accessed April 2011 ${ }^{6}$ Case C-249/96 [1998], Lisa Jacqueline Grant v. South-West Trains Ltd, ECR I-621. http://www.hrcr.org/safrica/equality/ Grant_South-West\%20Trains.htm accessed April 2011 
The Industrial Court requested that the ECJ provide the interpretation of Article 119 of the AEC (current Article 141) $)^{7}$ and the Directive 76/207 of the EEC. Among other things, the Industrial Court demanded the answers to the following two questions: "Whether, with a view to the interpretation of Article 119 of the AEC, "discrimination on grounds of gender" includes discrimination on grounds of sexual orientation of an employee and whether, with a view to the interpretation of Article 119 of the AEC, "discrimination on grounds of gender" includes discrimination on grounds of the sex of employee's partner".

In order to determine whether discrimination occurred, the ECJ believes that the comparison needs to be made between a male and female that shall indicate if an employer treats female persons in a different way than male persons and vice versa. Neither party agreed to the comparison given by the ECJ. The SWTL representatives claimed that the proper comparison should be between Lisa Grant, the lesbian and gay men, with the arguments that the SWTL does not grant travel benefits to the couples in same-sex marriages. Lisa Grant claimed that the comparison needs to be made between her and the heterosexual married couple. She exemplified this by stating that Mr. Poter, the SWTL employee, was granted travel benefits for his unmarried partner and that she is in the same position as Mr. Poter but she was not granted the benefits for her partner. It is evident that Lisa Grant emphasized the issue of discrimination on grounds of gender in relation to her partner, meaning different treatment of male and female partner. Besides the argument that this is a case of discrimination on grounds of gender, Grant also emphasizes the alternative argument under which the ECJ needs to include sexual discrimination in the term discrimination on grounds of gender. Lisa Grant's arguments were supported by the verdict/ruling in the case P. $v S$. and Cornwall County Council ${ }^{8}$, in which the ECJ, by specifying the purpose of the Directive 76/207 EEC, stated that the Directive is to outlaw discrimination on grounds of gender of all persons, thus expanding the understanding of sexual discrimination out of the scope of a In such a way, the ECJ provided the opportunity for

\footnotetext{
${ }^{7}$ See Article 141 (ex Article 119) of the EU Treaty

${ }^{8}$ In cases P. v S. and Cornwall County Council ESP is concluded: „Where such discrimination arises, as in the present case, from the gender reassignment of the person concerned, he or she is treated unfavourably by comparison with persons of the sex to which he or she was deemed to belong before undergoing gender reassignment. To tolerate such discrimination would be tantamount, as regards such a person, to a failure to respect the dignity and freedom to which he or she is entitled, and which the Courthas a duty to safeguard. Case C-13/94 [1996], P. v. S. and Cornwall County Council, Judgment of the Court of 30 April 1996. http://homepage.univie.ac.at/elisabeth .holzleithner/EuGHPvS1996.pdf accessed April 2011
}

homosexual persons to seek protection like transsexuals (Spacknlan, 1997, pp. 1109-1110).

Lisa Grant's arguments were also supported by the decision of the Human Rights Committee in the case of Toonen v. Australia'. In this case, the Committee took a stand that "sex", as defined in the provisions of the International Covenant on Citizen and Political Rights, includes sexual orientation.

Having examined and analyzed the case $P . v . S$. and Cornwall County Council (hereinafter the case P.), general public attorneys stated the court interpretation that the scope of the Directive 76/207 EEC cannot be limited only to the discrimination on grounds of partner's sex. The ECJ provided a wider interpretation of the principle of equal treatment in a way that is adequate for the cases of discrimination on grounds of gender that occur in the modern society. The cases such as P. and Grant show that nowadays an employer can discriminate against his/her employees not only on the basis of sex but on the basis of the sex of their partner, brothers or sister etc (Spacknlan, 1997, p. 1116). A detailed analysis of the SWTL regulations, particularly the rule number 8 of the Rulebook on employee privileges which specifies the benefits for the partners of different sexes that are not married, it is evident that in this case there is an issue on partner's sex. Based on this, general public attorneys conclude "employer's regulation by which the travel benefits are granted to the partner of different sex that the employee and refused for employee's partner of the same sex is a discrimination on grounds of gender which is an integral part of Article 119 of the EC Agreement" Spacknlan, 1997, p. 1117).

The ECJ ruled that denying travel benefits for the samesex partner of Ms. Grant is not discrimination on grounds of gender and that stabile same-sex relationships are not equalized to marriage of stabile common-law marriage between the persons of different sexes. Thus, the ECJ rejected the extension of discrimination on grounds of gender to discrimination on grounds of sexual orientation, neglecting the views of general public attorneys that were in favor of Lisa Grant. The ECJ also states that the EC law does not regard stabile relationships between the same-sex persons as equivalent to the marriage or common-law marriage of the persons of different $\operatorname{sexes}^{10}$.

${ }^{9}$ Toonen v. Australia, United Nations Human Rights Committee (Views on Communication, No 488/1992, adopted 31 March 1994) International Covenant on Civil and Political Rights, art 17 - optional protocol, art 5 - privacy and sexual orientation Tasmanian Criminal Code. http://www.austlii.edu.au/au/journals/PLPR/1994/33.html accessed May 2011

${ }^{10}$ Para 35. Lisa Jacqueline Grant v. South-West Trains Ltd. 
In terms of claims that the Human Rights Committee took a stand that discrimination on grounds of gender includes discrimination on grounds of sexual orientation as well, the ECJ states that the Human Rights Committee is not a legal instance and that its decisions are not legally binding.

Such stands do not reflect so far generally accepted interpretations of the term "discrimination on grounds of gender" that appear in various international documents that protect the basic rights and they by no means can represent the basis for expansion of the scope of Article 119 of the Agreement. The analysis of the case leads to the conclusion that the EC law currently does not cover discrimination on grounds of sexual orientation, when it appears as meritum ${ }^{11}$.

\section{$D$ and Kingdom of Sweden v. Council of the Euro- pean Union}

In the case D and Kingdom of Sweden v. Council of the European Union ${ }^{12}$, Mr. D. is an officer of the Council of the European Union (hereinafter the EU Council), and he has Swedish citizenship. In 1995 in Sweden he registered partnership with another Swedish citizen. In 1996, Mr. D. made an appeal to the Council that his status of registered partner is treated equally to the status of married partners, in order to regulate the household allowance, specified by the Council Directive 781/98. By this Directive, the household allowance was granted only to the employees that were married and the employees that were not married but who had children to support ${ }^{13}$. Swedish law provided the equal treatment to the same-sex registered partners and married couples. The EU Council rejected Mr. D.'s appeal stating that the provisions of the Directive 781/98 cannot be interpreted in a way that registered same-sex partnership is equal to marriage.

Swedish law provided the equal treatment to the same-sex registered partners and married couples.

\footnotetext{
${ }^{11}$ Para 47. Lisa Jacqueline Grant v. South-West Trains Ltd.

${ }^{12}$ Judgment of the Court of 31 May 2001. - D and Kingdom of Sweden v. Council of the European Union. - Appeal - Official - Household allowance - Married official - Registered partnership under Swedish law. - Joined cases C-122/99 P and C-125/99 P. http://eur-lex.europa.eu/LexUriServ/LexUriServ. do?uri=CELEX:61999J0122:EN:HTML accessed April 2011

${ }^{13}$ In 2004, amendments to the Directive ensured equal treatment in terms of acquiring rights to household allowance for both married persons and persons in registered partnership. See Annex, Article 1/2/c/i.
}

The EU Council rejected Mr. D.'s appeal stating that the provisions of the Directive 781/98 cannot be interpreted in a way that registered same-sex partnership is equal to marriage.

Supported by the Kingdom of Sweden, Mr. D. filed a suit to the Court of First Instance. The Court rejected his appeal stating that the concept of marriage needs to be understood in the traditional sense and that referring to the laws of the member states is not necessary at the instances where the Directive provision exists, which demands an independent interpretation. The Court believed that the EU Council does not have the obligation to assign the stabile same-sex union the same rights given to marriage. In this case, the EU Council is not the legislator but the employer. Mr. D. and the Kingdom of Sweden (supported by Denmark and Holland) filed a suit to the ECJ.

Deciding in the case of Mr. D., the ECJ accepts the fact that the same-sex registered partnership is legalized in some member states, although not completely, but that the term spouse, pursuant to the Directive $781 / 98$, cannot be used for the person whose status is different from the person who is married and that the Court cannot change these provisions. Only the legislator, should he believe it is appropriate, change the given situation, for example by changing the Directive provisions ${ }^{14}$. In terms of the claims that this is a case of discrimination on grounds of gender, the ECJ uses the same arguments as in the Grant case. The Court emphasizes that it is irrelevant, in terms of granting the right to the household allowance, whether the employee is male or female. Whether the applicant shall be given the right to the household allowance depends on the legal nature of the relationship between the employee and his/her partner ${ }^{15}$. The ECJ supported the verdict of the Court of First Instance that the term "marriage" in the Directive 789/98 demands an independent interpretation and that the interpretation whether partnership is considered as marriage is under the jurisdiction of the Court.

\footnotetext{
${ }^{14}$ Para 38. D and Kingdom of Sweden v. Council of the European Union.

${ }^{15}$ Para 47. D and Kingdom of Sweden v. Council of the European Union.
} 
The Court emphasized that there are tendencies for the legalization of the same-sex unions, but also that such unions are characterized by "great diversity" and that "by observing such unions in the member states, it is evident that they differ from marriage". Under such circumstances, the Court states that the provisions of Community law, in the definition of the term "marriage", cannot be interpreted in such a way that they include homosexual partnerships officially registered by the laws of the member states and that they need to be interpreted by the legislator ${ }^{16}$. The intention of the legislator in this case was not to grant household allowances to the same-sex partners.

\section{Tadao Maruko v. Versorgungsanstalt der deutschen Bühnen}

Tadao Maruko v. Versorgungsanstalt der deutschen Bühnen ${ }^{17}$ is the first case before the ECJ in which discrimination on grounds of sexual orientation was established beyond dispute. Mr. Maruko lived with his partner in the registered same-sex partnership. After the death of his partner, the Pension Insurance of the German National Theater refused to pay him family pension since such pensions were predicted only for married couples. Mr. Maruko filed a suit against the German National Theater. The Bavarian Administrative Court in Munich requested from the ECJ the interpretation of the Directive 200/78/EC that is related to the equality at work place. The ECJ decided that "rejecting the request for family pension to the living same-sex partner is a direct discrimination on grounds of gender, provided that such right in the comparable situation is available to married partners "18. Although the decision in the case Maruko seems revolutionary, in terms of the protection of rights of homosexual persons, it has two disadvantages. The first one is evident in the fact that the ECJ in the case Maruko failed to provide protection there where it was needed the most, namely, in those legal systems that do not recognize any institute of the union of life of the same-sex persons. In other words, according to the ECJ, for direct discrimination to oc

\footnotetext{
${ }^{16}$ Para 36 i 37. D and Kingdom of Sweden v. Council of the European Union.

${ }^{17}$ Case C-267/06, Tadao Maruko v. Versorgungsanstalt der deutschen Bühnen. http://eurlex.europa.eu/LexUriServ/LexU riServdo?uri=CELEX:62006J0267:EN:HTML accessed April 2011

${ }^{18}$ Para 72. Tadao Maruko v. Versorgungsanstalt der deutschen Bühnen.
}

cur, a legalized same-sex union needs to exist in a given state in order to compare same-sex union and marriage. The second disadvantage of the decisions is that the ECJ retains the stand that further definition and identification of the points regarding further legal steps of the European Union, in the given state, are completely ceded to the member states (Toggenburg, 2008).

The decisions of the ECJ point to the fact that marriage, as a traditional institute, remains under the exclusive jurisdiction of the member states. What is visible in the ECJ decisions is the fact that there is no intention for imposing the legalization of the same-sex marriage on the member states. However, the ECJ clearly sent a clear signal to the member states that they need to arrange their jurisdictions in terms of family relations in the ways that are in accordance to the EU law, especially respecting the provisions on the prohibition of discrimination. This means that the limitations, specified in the national laws, which are related to limitations of certain rights to the unmarried persons, need to be justified in order to be in accordance to the EU law. Should such limitations proved to be unjustifiable, the member states need to ensure alternative ways and forms for unmarried persons to be granted certain benefits.

Until the Maruko case, the ECJ strongly defended the member states and their stands on certain benefits to be granted to married partners only (cases Grant and D.). In the Grant case, the ECJ not only allowed for different treatment of marriage partners in relation to the unmarried persons, but it also gave its blessing for a different treatment in terms of homosexual and heterosexual couples without any justifiable rationales.

It is necessary to critically observe the interpretation of the term "the current state of the member state law", which is used by the Court when establishing the difference between same-sex and heterosexual union of life. In the Maruko case it is evident that the ECJ approach leads to the situation that the changes in the EU laws are completely dependant on the member state legislators. Now, when the Directives clearly prohibit discrimination on grounds of sexual orientation, the Court shall need to adopt a more sophisticated approach, due to the fact that it also has an active role in preventing any discrimination including sexual discrimination. Provided that the ECJ stand by the interpretation in the Maruko case that the regulation of family and marriage should be under exclusive jurisdiction of the member states, there is a danger that it fails the test of preserving the principles of non-discrimination in the EU law (Toggenburg, 2008, p. 14). 
When the ECJ is faced with the discrimination of language minorities, it does not compare two groups of people within the member state (Toggenburg, 2008, p.16). Instead, it compares whether they are in the the same situations and answers the question "whether their language is equal". Those who are de facto in the same situations should de iure have the same rights and benefits, provided that such limitation is justifiable. Such approach should be applied not only in the context of proving beyond dispute discrimination of minorities. In cases where the member states, by granting certain benefits, make differences between heterosexual and homosexual unions of life, the ECJ, when implementing the Directives on prohibition of discrimination, should not do so in relation to de iure existence or specificities of unions of life. The comparability of the unions of life should depend on the fact whether de facto situations can be compared in that particular context.

\section{Jürgen Römer v. Freie und Hansestadt Hamburg}

In the case Jürgen Römer v. Freie und Hansestadt Hamburg $^{19}$, the ECJ rules that the additional pension paid to the registered partner, which is lower that the one guaranteed to the married partner, can be discrimination on grounds of sexual orientation. Mister Römer, based on pension recalculation, would double his monthly income. In this case, Mister Römer was a municipal employee in Hamburg from 1950 until he retired.

From the year of 1969 he lived with his same-sex partner Mr. U., with whom he registered life partnership on October 15, 2001. Mr. Römer notified his former employer on his partnership requesting for the recalculation of the additional amount of pension, meaning that his new status be recognized. However, his request was rejected due to the fact that the valid German law only married pensioners are granted higher pensions.

In his lawsuit filed before the Court in Hamburg, Mr. Römer claimed that he has the right to the pension equal to those given to the married partners, in accordance to the regulations of the European law. The Court in Hamburg decided to suspend the procedure and request the ECJ to provide answers to the follow-

\footnotetext{
${ }^{19}$ Case C 147/08, Jürgen Römer v. Freie und Hansestadt Hamburg, 10 May 2011. http://eur-lex.europa.eu/LexUriServ/LexUriServ.do?uri=CELEX:62008J0147:EN:HTML accessed May 2011
}

ing questions "Does the Directive 2000/78 EC that prohibits discrimination on grounds of gender apply to pension as well?" and "Whether different treatment on the basis of marital status leads to the Directive violation?"

After it was established that, in accordance to the Directive 200/78EC, the Pension Insurance is in this case obliged to pay the compensation, the ECJ, when deciding on the meritum, finds that Germany legalized registered partnership to the same-sex couples that are deprived of the right to marriage thus gradually extending the rights related to these partnerships in the way that they are comparable (although not equal) to marriage. The ECJ emphasized that during his active life Mr. Römer regularly paid the pension fund contributions equal to those made by his colleagues in heterosexual marriages. The Court established that in this particular case, Mr. Römer's right depends on his sexual orientation.

Replying to the question regarding discrimination, the ECJ states that the relevant provisions of European law "prevent the provisions of the national laws ... under which the pensioner who registered same-sex partnership received the pension lower that the one granted to the married persons ... provided that, in the member state, marriage is exclusively reserved for the persons of different sexes and exists along with the registered partnership, as specified by the German law that prescribes that marriage is reserved for the persons of different sex, and if in that member state $(\mathrm{A} / \mathrm{N})$ that there is direct discrimination on grounds of sexual orientation since the national law states that the life partner is legally and factually comparable to the persons in marriage in the pension-related issues ${ }^{20}$ ". In other words, European law imposes the principle of non-discrimination while the national courts are obliged to establish all the facts in order to determine whether marriage and same-sex registered partnership are comparable in the case of Mr. Römer. By describing the task of the German court in this specific case, the ECJ states "The court of jurisdiction has the obligation to asses the comparability, focusing on the appropriate rights and duties of marriage partners and persons in the registered partnership, as specified by the appropriate relevant institutions considering the purpose and conditions for granting this benefit"21.

\footnotetext{
${ }^{20}$ Para 44. Jürgen Römer v. Freie und Hansestadt Hamburg. ${ }^{21}$ Para 67. Jürgen Römer v. Freie und Hansestadt Hamburg.
} 


\section{CONCLUSION}

Based on the analysis of the ECJ practice in the cases related to the rights of the same-sex partners, it can be concluded that this Court has started to increasingly protect the rights of the same-sex partners in the situations when same-sex partnerships have been legalized under the national laws, referring to the principle of non-discrimination. However, the issue of the legalization of the same-sex union of life is still under the jurisdiction of the member states whereby the rights of the same-sex partners remain unprotected in those countries that have not legalized the union of life of the same-sex persons.

\section{REFERENCES}

Case C-249/96 [1998], Lisa Jacqueline Grant v. South-West Trains Ltd, ECR I-621.

Case C-13/94 [1996], P. v. S. and Cornwall County Council, Judgment of the Court of 30 April 1996.

Human Rights Committee Communication No. 488/1992 (Toonen v Australia).

Judgment of the Court of 31 May 2001. - D and Kingdom of Sweden v. Council of the European Union. - Appeal - Official Household allowance - Married official - Registered partnership under Swedish law. - Joined cases C-122/99 P and C-125/99 P. Spacknlan, L. P. (1997). Grant v. South-West Trains: Equality for Same-Sex Partners in the European Community, American University International Law Review, 12(6).

Toggenburg, N. G. (2008). LGBT rights before court of justice, European Law Reporter 5/2008. www.ilga-europe.org/.../LGBTRights $\% 20$ before $\% 20$ the $\% 20$ European $\% 20$ Court $\% 20$ of $\% 20$ Justice.pdf. Accessed April 2011.

The Treaty of Lisbon, Official Journal of the European Union C 306, 17.12.2007.

Case C-267/06, Tadao Maruko v. Versorgungsanstalt der deutschen Bühnen.

Case C 147/08, Jürgen Römer v. Freie und Hansestadt Hamburg. 